\title{
SKI wt Allele
}

National Cancer Institute

\section{Source}

National Cancer Institute. SKI wt Allele. NCI Thesaurus. Code C49426.

Human SKI wild-type allele is located within 1q22-q24 and is approximately $81 \mathrm{~kb}$ in length. This allele, which encodes ski oncogene protein, is involved in neural tube development and muscle differentiation. Deletion of the gene may be associated with congenital fiber-type disproportion myopathy and dilated cardiomyopathy. Aberrant elevated expression of the gene may play a role in tumorigenesis. 